\title{
Alterations in Chlorophyll $a$ Fluorescence and Pigments Concentration in the Leaves of Cauliflower and Broccoli Transplants Subjected to Chilling
}

\author{
Renata WOJCIECHOWSKA ${ }^{1}$, Andrzej KALISZ ${ }^{2 *}$, Agnieszka SĘKARA², \\ Michał NOSEK ${ }^{3}$, Stanisław CEBULA ${ }^{2}, Z_{\text {Zbigniew MISZALSKI }}^{4}$, \\ Edward KUNICKI², Aneta GRABOWSKA ${ }^{2}$
}

\author{
${ }^{1}$ University of Agriculture in Krakow, Faculty of Biotechnology and Horticulture, Institute of Plant Biology and Biotechnology, Unit of Botany and Plant Physiology, \\ 29Listopada54,31-425Kraków,Poland; r.wojiechowska@ogr.ur.krakow.pl \\ ${ }^{2}$ University of Agriculture in Krakow, Faculty of Biotechnology and Horticulture, Department of Vegetable and Medicinal Plants, 29 Listopada 54,31-425 Kraków, \\ Poland;akalisz@ur.krakow.pl(*correspondingauthor);asekara@ogr.ur.krakow.pl;s.cebula@ogr.ur.krakow.pl;.ekunicki@ogr.ur.krakow.pl;agrabouska@ogr.ur.krakow.pl \\ 3Pedagogical University ofKrakow, InstituteofBiology,Podchorażych2,30-084Kraków,Poland;minos@up.krakow.pl \\ ${ }_{4}^{4}$ Jagiellonian University, Malopolska CentreofBiotechnology, Gronostajowa 7A, 30-387Kraków, Poland;zbigniew.miszalski@uj.edu.pl
}

\begin{abstract}
Chlorophyll a fluorescence parameters and photosynthetic pigments content in leaves of broccoli (Brassica oleracea L. var. italica) cv. 'Monaco' $F_{1}$ and cauliflower (Brassica oleracea L. var. botrytis) cv. 'Bruce' $F_{1}$ transplants were analyzed to investigate the effects of chilling temperatures $\left(6\right.$ and $\left.10^{\circ} \mathrm{C}\right)$ and the exposure length $(1$ or 2 weeks) on the photosynthetic apparatus condition in 3-year experiment. Data were compared to control plants exposed to $14^{\circ} \mathrm{C}$ for 1 and 2 weeks. The lowest values of maximum quantum efficiency of photosystem II $\left(\mathrm{F}_{\mathrm{v}} / \mathrm{F}_{\mathrm{m}}\right)$ and the performance index (PI) were observed in cauliflower chilled at $6^{\circ} \mathrm{C}$ for 2 weeks. This was not accompanied by any substantial reduction in chlorophylls concentration, however, significant correlations between $\mathrm{F}_{\mathrm{v}} / \mathrm{F}_{\mathrm{m}}$ or PI and chlorophylls content in cauliflower leaves were found. There was no negative effects of chilling on photosynthetic activity and chlorophyll content in broccoli leaves, the amount of carotenoids significantly increased in the broccoli chilled for 2 weeks in $6^{\circ} \mathrm{C}$. The chlorophyll $a$ fluorescence indices and accelerated carotenoids synthesis showed that broccoli had less vulnerable photosynthetic apparatus to stress-induced temperatures and more efficient protection mechanisms in comparison to cauliflower transplants.
\end{abstract}

Keywords: Brassica crops, carotenoids, chlorophylls, low temperature, $\mathrm{F}_{\mathrm{v}} / \mathrm{F}_{\mathrm{m}}$, performance index

\section{Introduction}

Abiotic stresses are major environmental factors that significantly affect plant growth and productivity, leading to substantial yield losses (Hasanuzzaman et al., 2013). An important fact is that plant species and their ecotypes developed various physiological mechanisms underlying abiotic stress responses (Sharma et al., 2012).

One of the earliest responses of plant cells under chilling conditions is the generation of large quantities of reactive oxygen species (ROS) (Bhattacharjee, 2005; Suzuki and Mittler, 2006; Pospísil, 2012). Exposure to low temperature may lead to overproduction of ROS, affects cellular components through damage to nucleic acids, protein oxidation, and lipid peroxidation (Sharma et al., 2012), ultimately results in oxidative stress, often requiring the involvement of several antioxidant enzymes or lowmolecular antioxidants (Turan and Ekmekci, 2011). Excessive production of ROS can disturb photosynthesis due to disarrangement of thylakoid ultrastructure (Kratsch and Wise, 2001), inhibition of de novo synthesis of D1 protein, which is needed for PSII repair (Nishiyama et al., 2011), and suppression of some chloroplast enzymes activities (Kato and Sakamoto, 2014). The inherent feature of the photosystem II complex is its vulnerability to abiotic stresses, including chill-induced oxidative stress, significantly disturbing photosynthetic process (Murata, 2007; Gururani et al., 2015).

Monitoring changes in $\mathrm{F}_{\mathrm{v}} / \mathrm{F}_{\mathrm{m}}$ can be useful for revealing different responses of various plant species to chilling temperatures (Strauss $e t$ al., 2006; Mishra et al., 2011; Gorbe and Calatayud, 2012). Measurement of chlorophyll $a$ fluorescence is a simple and noninvasive technique that has been successfully used for the evaluation of photosynthetic activity under environmental stresses (Gorbe and Calatayud, 2012; Ashraf and Harris, 2013). The consequences of damage to the photosynthetic apparatus, caused by chill-induced oxidative stress, are reflected by changes in the chlorophyll a 
18

fluorescence parameters which was frequently reported and widely discussed (Strauss et al., 2006; Dutta et al., 2009, Oliveira et al., 2009; Gorbe and Calatayud, 2012; Guidi and Deg'Innocenti, 2012). The $\mathrm{F}_{\mathrm{v}} / \mathrm{F}_{\mathrm{m}}$ value is a measure of the maximum efficiency of PSII. Its optimal value, found in intact and healthy plants of most species, is about 0.830 (Guidi and Deg'Innocenti, 2012), while, for stressed plants, $F_{v} / F_{m}$ values tend to decline. Jansen et al. (2009), in experiments on Arabidopsis thaliana plants exposed to lowtemperature stress $\left(5^{\circ} \mathrm{C}\right)$, observed a slow decrease in the $F_{v} / F_{m}$ values in two tested lines (polymerase-deficient PARP and C24 wild type) - until below 0.730 or 0.700 (the difference was due to genetic line). Among fluorescence parameters, the PI, also known as the "performance index" or "vitality index", reflects the three main functional steps of photosynthetic activity by a PSII reaction center complex: light energy absorption, trapping of excitation energy, and conversion of excitation energy to electron transport (Strauss et al., 2006). The PI parameter indicates the functionality of both photosystems (PSI and PSII) and provides quantitative information on the current state of plant performance under stress conditions (Strasser et al., 2004). This parameter, as $\mathrm{F}_{\mathrm{v}} / \mathrm{F}_{\mathrm{m}}$, is usually reduced by the chilling temperature. Sun et al. (2009) subjected watermelon juvenile plants to chilling $\left(4^{\circ} \mathrm{C}\right)$ and they observed significant decrease in performance index as compared to the control. The performance index is also capable to reveal differences among plant genotypes. For example, Van Heerden et al. (2004) showed that dark chilling $\left(8^{\circ} \mathrm{C}\right.$ for 1 night $)$ did not decrease the PI parameter of chill-tolerant soybean while in chill-sensitive genotype the PI was $26 \%$ lower than in control plants.

Low temperature slows down the metabolism of the transplants, impairing the biosynthesis of main photosynthetic pigments as well as chloroplast development (Yadegari et al., 2007; Dutta et al., 2009). Plants subjected to low-temperature conditions may optimize their photosynthetic apparatus, since the activity of the enzymes of the main metabolic pathways is significantly down-regulated. In this case, demands of light absorption and utilization are lowered. Chlorophyll concentrations optimal for moderate temperatures become a heavy burden for a cell in lower temperatures, especially with long-acting stress stimulus (Murata et al., 2007). Some of the absorbed light quanta would be counted as excess energy that often initiates singlet oxygen overproduction, followed by photooxidative damage and cell death. Decreasing chlorophyll content in plant leaves under low temperature is often considered a typical symptom of oxidative stress (Yadegari et al., 2007). This was shown, for example, in chill-sensitive coffee seedlings (Oliveira et al., 2009), different rice genotypes (Zhang et al., 2010; Perveen et al., 2013), wheat (Habibi et al., 2011), and chill-sensitive maize cultivars (Aroca et al., 2001). Partelli et al. (2009) reported that coffee plants responded with a $30 \%$ reduction in chlorophyll $a$ content and $27 \%$ reduction in chlorophyll $b$ when the day/night temperature decreased from $25 / 20$ to $13 / 8^{\circ} \mathrm{C}$.

Abiotic stresses induce an "alarm phase", characterized with functional declines due to the stressor factor. Photosynthesis and photosynthesis-related pigments are directly affected by low temperature, which is manifested by decreases in plant photosynthetic efficiency and capacity (Ruelland et al., 2009; Ruelland and Zachowski, 2010; Theocharis et al., 2012). If intensity of the stress stimulus is not lethal and exposure to stress is not prolonged, plants may reestablish their homeostasis, repair cellular components, and reprogram the metabolic system (Wang et al., 2003; Suzuki et al., 2011).
In temperate climate, cauliflower and broccoli planted in the field during early spring may experience multiply environmental stresses, for example low above-zero temperatures or ground frosts. Controlled stress, applied to plants before planting out, through lowering the temperature, activates acclimation process, and provides an improvement of plant tolerance to a subsequent stress (Hasanuzzaman et al., 2013). Chilling may play a regulatory role in cross-adaptation of the plants, in which pre-exposure to one stress confers tolerance to other types of stresses also (Thakur and Nayyar, 2013). It is important because crops with enhanced tolerance to field environment may potentially exhibit higher yields (Kalisz et al., 2014). The question is which combination of low temperature and chilling duration will be safe enough for cauliflower and broccoli transplants to launch the process of acclimation and not cause permanent damages to the photosynthetic apparatus. We assume that these plants, exposed to chilling treatment, predisposing them to outdoor production, may show lesser disturbances in photosynthetic activity and pigments content than thermophilic plants (KingstonSmith et al., 1999; Liu et al., 2001; Lukatkin et al., 2012; Sharma et al., 2012). We also expect the differences between broccoli and cauliflower crops in response to stress, which should be helpful to estimate their sensitivity to low temperature. Results published by Długosz-Grochowska et al. (2012) and Grabowska et al. (2014) suggest that broccoli is relatively tolerant to chilling temperatures, while the response of cauliflower plants to environmental conditions is stronger in comparison to broccoli, and the species seems to be more affected by extreme thermal factors (Diputado, 1989; Olesen and Grevsen, 2000). However, direct comparative studies of broccoli and cauliflower responses to low temperature treatment are scarce and very difficult to achieve. Within this context, our main purpose was: (1) to check the $\mathrm{F}_{\mathrm{v}} / \mathrm{F}_{\mathrm{m}}$ of PSII and the PI parameters of the plants exposed to temperatures of 6 and $10^{\circ} \mathrm{C}$; (2) to evaluate plants' photosynthetic apparatus respond when measured after 1 and 2 weeks of chilling; (3) to determine the changes in the pigments content of the transplant leaves previously subjected to chilling; (4) to compare sensitivity of Brassica crops at transplant stage to low temperature.

\section{Materials and Methods}

\section{Plant material and chilling treatment}

The experiments with 'Bruce' $F_{1}$ cauliflower (Brassica oleracea L. var. botrytis) and 'Monaco' $F_{1}$ broccoli (Brassica oleracea L. var. italica) were carried out at the University of Agriculture in Krakow, Poland, in 2011, 2012, and 2013. The seeds, obtained from Syngenta Seeds (Warsaw, Poland) were sown March 8-11 using multipots (VEFI, 96 cells, $53 \mathrm{~cm}^{3}$ single-cell volume) filled with standard peat substrate (Klasman TS2, Klasmann-Deilmann $\mathrm{GmbH}$, Geeste, Germany). The pots were then placed in the greenhouse. The temperature in the greenhouse was maintained at $24 \pm 2{ }^{\circ} \mathrm{C}$ until emergences, and then the plants were grown at approximately $18 / 16 \pm 2{ }^{\circ} \mathrm{C}$ (day/night) up to chilling treatment. Plants were watered when necessary and fertilized twice (21 and 29 days after sowing) with a soluble fertilizer Yara Kristalon Zielony $\left(18 \% \mathrm{~N}, 18 \% \mathrm{P}_{2} \mathrm{O}_{5}, 18 \% \mathrm{~K}_{2} \mathrm{O}, 3 \% \mathrm{MgO}\right.$, and $2 \% \mathrm{~S}$ ) (Yara International ASA, Oslo, Norway), at a dose of $10 \mathrm{~g} \mathrm{dm}^{-3}$ water. The 40-day-old transplants of cauliflower and broccoli were transferred to vegetative chambers with a 14 h photoperiod (Sunmaster metal halide lamps, LM 400W U46CDX, Venture Lighting Europe Ltd., Rickmansworth, UK). The intensity of 
irradiance at canopy level was $\sim 300 \mu \mathrm{mol} \mathrm{m} \mathrm{s}^{-2}$, and the relative humidity RH was $\sim 75 \%$. Next, the plants were exposed to chilling of varying intensities. We investigated the effects of chilling duration (for 1 and 2 weeks) and chilling temperature at the constant level of 6 and $10{ }^{\circ} \mathrm{C}$. Additional treatments of $14^{\circ} \mathrm{C}$ maintained for 1 and 2 weeks, with the same irradiance intensity and relative air humidity, served as the control. The control reflects average temperature conditions acting on the broccoli and cauliflower plants after planting them to the field in Poland spring conditions.

\section{Chlorophyll aftuorescence}

The parameters of chlorophyll $a$ fluorescence were quantified using a portable Handy Plant Efficiency Analyzer (Handy-PEA, Hansatech Instruments, Norfolk, UK). At the end of chilling period, 20 randomly selected plants (5 plants over 4 replications) of each treatment and variety were moved from the chambers to the laboratory. Healthy and fully expanded leaf was selected from the plants (6 leaves of 6 different plants per treatment). The leaves were dark-adapted for $20 \mathrm{~min}$ prior to the measurements and then were illuminated by using the saturation pulse method (intensity: 1500 $\left.\mu \mathrm{mol} \mathrm{m} \mathrm{m}^{-1}\right)$. Two main parameters were measured: maximum quantum yield of PSII $\left(\mathrm{F}_{\mathrm{v}} / \mathrm{F}_{\mathrm{m}}\right)$ and performance index $(\mathrm{PI})$. The yield of variable fluorescence $F_{v}$ was calculated as $F_{m}-F_{0}$, where $F_{0}$ is the initial fluorescence value, and $F_{m}$ is the maximal fluorescence of a dark-adapted sample.

\section{Chlorophyll and carotenoids analyses}

Contents of plant pigments were evaluated in leaves in which fluorescence parameters previously had been determined. Tissues were extracted directly from plant leaves without freezing. Leaf samples were pool and measure was done in 4 replications. A 0.4 $\mathrm{cm}$-diameter discs were cut from the middle of the leaf, avoiding the midrib and major veins. Leaf samples $(0.1 \mathrm{~g})$ were grounded with addition of $3 \mathrm{mg}$ of magnesium carbonate $\left(\mathrm{MgCO}_{3}\right)$ as a pigment stabilizer and chlorophyll ( $\mathrm{Chl} a$ and $\mathrm{Chl} b$ ) and carotenoids (Car) were extracted in $80 \%(\mathrm{v} / \mathrm{v})$ aqueous acetone $\left(25 \mathrm{~cm}^{3}\right)$. After $0.5 \mathrm{~h}$ in the dark, obtained suspension was filtered through a filter paper (POCH SA, No. 978774513, Gliwice, Poland), and then the absorbance readings were carried out at 663, 646, and $470 \mathrm{~nm}$, respectively, using a Helios Beta spectrophotometer (Thermo Fisher Scientific Inc., Waltham, USA). The chlorophyll and carotenoids contents were calculated using the equations described by Lichtenthaler and Wellburn (1983). The ratios of chlorophyll $a$ to $b(\mathrm{Chl} a$ : $\mathrm{Chl} b)$ are also presented.

\section{Statistical analyses}

The results were statistically evaluated based on the two-way analysis of variance (ANOVA) procedure in the STATISTICA program (StatSoft Inc., v. 12, USA), with a Tukey's HSD (honest significant difference) test at 0.05, 0.01, and 0.001 levels of probability. Sources of variation were chilling temperature level $(\mathrm{T})$, treatment duration (D), and interactions between them $(\mathrm{T} \times \mathrm{D})$. For comparison direct response of tested $B$. oleracea crops to chilling temperatures, irrespectively of exposure length, two-way ANOVA involved main effects of the crop $(\mathrm{C})$, chilling temperature $(\mathrm{T})$, and their interactions $(\mathrm{C} \times \mathrm{T})$ was additionally performed. Correlation analyses for the relationships between chlorophyll a fluorescence parameters $\left(\mathrm{F}_{\mathrm{v}} / \mathrm{F}_{\mathrm{m}}, \mathrm{PI}\right)$ and the pigments content were performed for the cauliflower and broccoli transplants $(\mathrm{n}=18)$. Linear coefficient of correlation $(r)$ values were calculated and assessed at different significance levels $(\mathrm{p}<0.05 ; \mathrm{p}<0.01 ; \mathrm{p}<0.001)$.

\section{Results}

\section{Chlorophyll afluorescence}

The leaves of the cauliflower plants growing at $14^{\circ} \mathrm{C}$ for 1 week were characterized by high values of both $\mathrm{F}_{\mathrm{v}} / \mathrm{F}_{\mathrm{m}}$ and $\mathrm{PI}$ (Fig. 1). The significantly lower values of $F_{v} / F_{m}$ and PI were found after 1 week at both 6 and $10^{\circ} \mathrm{C}$. Further declines occurred after 2 weeks of chilling, but the lowest values of both parameters were observed only under the $6^{\circ} \mathrm{C}$ temperature treatment. The control temperature $\left(14^{\circ} \mathrm{C}\right)$ induced no significant modifications in $\mathrm{F}_{\mathrm{v}} / \mathrm{F}_{\mathrm{m}}$ during either time period. Most measured PI values of chilled plants were significantly lower compared to the control.

The temperature variants applied during the 1- and 2-week treatments did not induce any significant changes in $F_{v} / F_{m}$ in broccoli transplants (Fig. 2). The maximum quantum efficiency of PSII was not disturbed after 2-week long exposure to $14^{\circ} \mathrm{C}$; nonsignificant declines were noted in plants at temperatures of 6 and $10^{\circ} \mathrm{C}$. Interestingly, higher PI values were noted under $6^{\circ} \mathrm{C}$ compared to $14^{\circ} \mathrm{C}$, although differences were statistically insignificant.

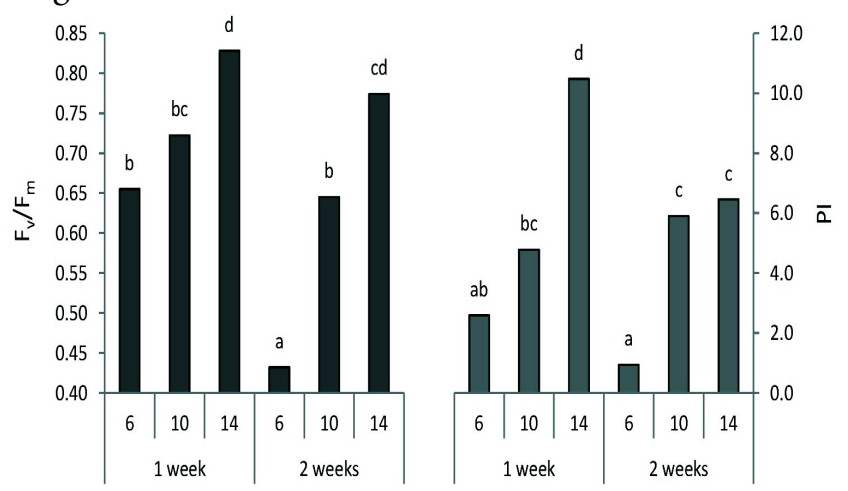

Fig. 1. Effect of different temperatures $\left(6,10,14^{\circ} \mathrm{C}\right)$ and length of their application ( 1 or 2 weeks) on the maximum quantum efficiency of PSII $\left(\mathrm{F}_{\mathrm{v}} / \mathrm{F}_{\mathrm{m}}\right)$ and the performance index (PI) in the leaves of cauliflower transplants (means for the years 2011-2013); means followed by the same letter are not significantly different at $p<0.05$ according to Tukey's HSD test

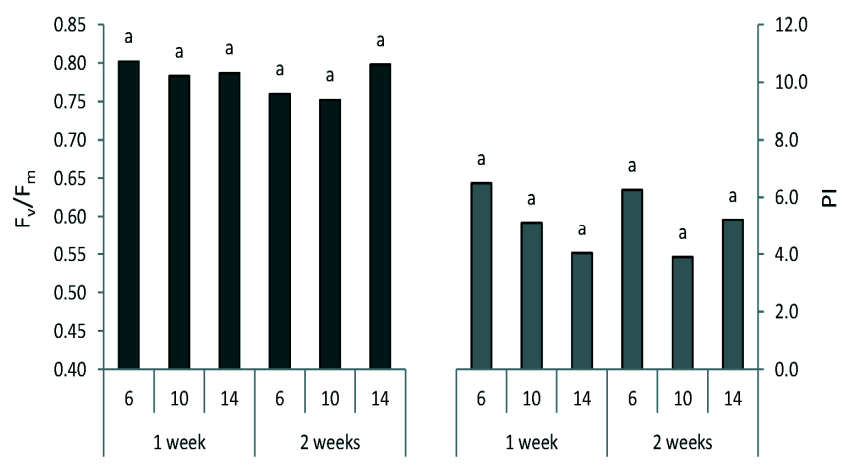

Fig. 2. Effect of different temperatures $\left(6,10,14^{\circ} \mathrm{C}\right)$ and length of their application ( 1 or 2 weeks) on the maximum quantum efficiency of PSII $\left(\mathrm{F}_{\mathrm{v}} / \mathrm{F}_{\mathrm{m}}\right)$ and the performance index (PI) of the leaves of broccoli transplants (means for the years 2011-2013); means followed by the same letter are not significantly different at $\mathrm{p}<0.05$ according to Tukey's HSD test 
20

Photosyntheticpigments content

We observed significant decrease of chlorophyll $a$ and $b$ contents in cauliflower plants treated with all temperature variants for 2 weeks (Table 1 ).

Chlorophyll a decline was not parallel with decreased temperature, and the lowest chlorophyll $a$ content was measured under control $\left(14^{\circ} \mathrm{C}\right)$. Temperature slightly affected chlorophyll $b$ content in leaves of cauliflower transplants. With decreasing temperature, a higher $\mathrm{Chl} a: \mathrm{Chl} b$ ratio was observed. Changes in the chlorophylls, as an effect of temperature treatments, were less differentiated in broccoli (Table 2) as compared to cauliflower. Prolonged treatment did not modify chlorophyll $a$ and chlorophyll $b$ concentrations in broccoli nor the $\mathrm{Chl} a$ : $\mathrm{Chl} b$ ratio. Generally, temperatures of 6 and $10^{\circ} \mathrm{C}$ caused some increases in the content of both chlorophylls compared to $14^{\circ} \mathrm{C}$, it was not statistically significant for chlorophyll $b$. An increase in the $\mathrm{Chl} a$ : $\mathrm{Chl} b$ ratio were noted for the plants treated with 6 and $10{ }^{\circ} \mathrm{C}$ temperatures.

Analysis of the carotenoid concentrations revealed that these pigments were affected by low temperature differently between cauliflower and broccoli transplants (Tables 1 and 2). In cauliflower leaves, the carotenoid contents were rather stable, and no interaction effects were observed. However, lower contents of these pigments in the plants treated with temperature variants for 2 weeks were noted. In broccoli, an increase was observed when plants were exposed to 6 and $10^{\circ} \mathrm{C}$, especially when applied for a 2-week period.

\section{Chlorophyll a fluorescence parameters versuspigments content}

A correlation analysis was performed to find relationships between chlorophyll $a$ fluorescence parameters and chlorophyll content. The results are presented in Table 3. All of the correlations were significant in the cauliflower transplants. The $\mathrm{F}_{\mathrm{v}} / \mathrm{F}_{\mathrm{m}}$ and PI parameters were positively correlated with the chlorophyll $a$ or chlorophyll $b$ contents or with the sum of the chlorophylls The highest correlation coefficients were found for both chlorophyll fluorescence parameters $\left(\mathrm{F}_{\mathrm{v}} / \mathrm{F}_{\mathrm{m}}\right.$ and PI) and total chlorophyll content (chlorophyll $a+b$ ). We did not find any significant correlations between chlorophyll $a$ fluorescence and pigments for broccoli transplants.

\section{Response of Brassica oleracea crops to chilling}

Species and varieties may responded in different manner when exposed to extreme temperatures. In present study, additionally made statistical analysis involved chilling temperatures and Brassica oleracea varieties (cauliflower, broccoli), irrespective of chilling duration, showed that photosynthetic apparatus of cauliflower plants was more sensitive to low temperature action (Table 4). Maximum photochemical efficiency of PSII $\left(\mathrm{F}_{\mathrm{v}} / \mathrm{F}_{\mathrm{m}}\right)$ and performance index (PI) decreased significantly in cauliflower with lowering temperature. These fluorescence parameters were not affected by chilling in broccoli. In the case of $\mathrm{F}_{\mathrm{v}} / \mathrm{F}_{\mathrm{m}}$ of broccoli transplants, differences between control $\left(14^{\circ} \mathrm{C}\right)$ and chilling temperatures were amounted to about $3 \%$, while for cauliflower they were larger than $30 \%$. No response to low temperature in carotenoids content was observed for cauliflower plants, while the lowest tested temperature $\left(6^{\circ} \mathrm{C}\right)$ increased significantly content of these pigments in broccoli in comparison to control. Analysis of interaction effects did not prove any significant alteration in chlorophyll a content, for each tested Brassica crops subjected to chilling as compared to the control, although these pigments concentration tended to be higher in lower temperature. Chl $a$ : $\mathrm{Chl} b$ ratio increased due to chilling treatment in both crops, more spectacularly in cauliflower transplants.

Table 1. Carotenoids (Car), chlorophyll $a(\mathrm{Chl} a)$ and $b(\mathrm{Chl} b)$ content (expressed in $\left.\mathrm{mg} 100 \mathrm{~g} \mathrm{FW}^{-1}\right)$ and the ratio of chlorophylls $(\mathrm{Chl} a$ : Chl $b$ ) in cauliflower transplants leaves as an effect of temperature treatment (means of the years 2011-2013)

\begin{tabular}{|c|c|c|c|c|c|}
\hline Duration (weeks) & Temperature $\left({ }^{\circ} \mathrm{C}\right)$ & Car & $\mathrm{Chl} a$ & $\mathrm{Chl} b$ & $\mathrm{Chl} a: \mathrm{Chl} b$ \\
\hline \multirow{3}{*}{1} & 6 & $30.03 \mathrm{a}$ & $122.28 \mathrm{c}$ & $61.47 \mathrm{bc}$ & $1.989 \mathrm{c}$ \\
\hline & 10 & $32.18 \mathrm{a}$ & $123.97 \mathrm{c}$ & $62.26 \mathrm{bc}$ & $1.991 \mathrm{c}$ \\
\hline & 14 & $30.88 \mathrm{a}$ & $118.76 \mathrm{bc}$ & $63.83 \mathrm{c}$ & $1.861 \mathrm{~b}$ \\
\hline \multirow{3}{*}{2} & 6 & $30.62 \mathrm{a}$ & $104.71 \mathrm{ab}$ & $50.30 \mathrm{a}$ & $2.082 \mathrm{~d}$ \\
\hline & 10 & $28.98 \mathrm{a}$ & $112.25 \mathrm{abc}$ & $55.96 \mathrm{abc}$ & $2.006 c$ \\
\hline & 14 & $28.44 \mathrm{a}$ & $98.33 \mathrm{a}$ & $55.23 \mathrm{ab}$ & $1.780 \mathrm{a}$ \\
\hline Temperature $(\mathrm{T})$ & & ns & $*$ & ns & *** \\
\hline Duration (D) & & $*$ & *** & *** & $\mathrm{ns}$ \\
\hline $\mathrm{T} \times \mathrm{D}$ & & $\mathrm{ns}$ & $* * *$ & *** & $* * *$ \\
\hline
\end{tabular}

Note: Data were subjected to two-way ANOVA. Means within a column followed by different letters are significantly different at $\mathrm{p}<0.05$ according to Tukey's HSD test; the level of significance $\left({ }^{*}, \mathrm{p}<0.05 ;{ }^{* *}, \mathrm{p}<0.01 ;{ }^{* * *}, \mathrm{p}<0.001\right.$; ns, non-significant) for main effects (temperature level - T, treatment duration - D), and interactions between them $(\mathrm{T} \times \mathrm{D})$ was also shown.

Table 2. Carotenoids (Car), chlorophyll $a(\mathrm{Chl} a)$ and $b(\mathrm{Chl} b)$ content (expressed in $\left.\mathrm{mg} 100 \mathrm{~g} \mathrm{FW}^{-1}\right)$ and the ratio of chlorophylls $(\mathrm{Chl} a$ : Chl $b)$ in broccoli transplants leaves as an effect of temperature treatment (means of the years 2011-2013)

\begin{tabular}{|c|c|c|c|c|c|}
\hline Duration (weeks) & Temperature $\left({ }^{\circ} \mathrm{C}\right)$ & Car & Chl a & $\mathrm{Chl} \mathrm{b}$ & Chl a: Chl b \\
\hline \multirow{3}{*}{1} & 6 & $33.34 \mathrm{bc}$ & $124.46 \mathrm{~b}$ & $65.50 \mathrm{a}$ & $1.900 \mathrm{c}$ \\
\hline & 10 & $31.40 \mathrm{abc}$ & $120.41 \mathrm{ab}$ & $63.78 \mathrm{a}$ & $1.888 \mathrm{c}$ \\
\hline & 14 & $30.24 \mathrm{ab}$ & $111.92 \mathrm{ab}$ & $61.28 \mathrm{a}$ & $1.826 \mathrm{~b}$ \\
\hline \multirow{3}{*}{2} & 6 & $34.91 \mathrm{c}$ & $118.33 \mathrm{ab}$ & $61.01 \mathrm{a}$ & $1.940 \mathrm{c}$ \\
\hline & 10 & $32.38 \mathrm{bc}$ & $121.38 \mathrm{ab}$ & $62.71 \mathrm{a}$ & $1.936 \mathrm{c}$ \\
\hline & 14 & $27.98 \mathrm{a}$ & $107.13 \mathrm{a}$ & $60.66 \mathrm{a}$ & $1.766 \mathrm{a}$ \\
\hline Temperature $(\mathrm{T})$ & & $* * *$ & ** & ns & *** \\
\hline Duration (D) & & $\mathrm{ns}$ & ns & ns & ns \\
\hline $\mathrm{T} \times \mathrm{D}$ & & $* * *$ & $*$ & ns & *** \\
\hline
\end{tabular}

Note: Data were subjected to two-way ANOVA. Means within a column followed by different letters are significantly different at $\mathrm{p}<0.05$ according to Tukey's HSD test; the level of significance $\left({ }^{*}, \mathrm{p}<0.05 ;{ }^{* *}, \mathrm{p}<0.01 ;{ }^{* * *}, \mathrm{p}<0.001\right.$; ns, non-significant) for main effects (temperature level - T, treatment duration - D), and interactions between them $(\mathrm{T} \times \mathrm{D})$ was also shown. 
Table 3. Correlation coefficients $(r)$ at particular significance level $(\mathrm{p})$ between maximum quantum efficiency of photosystem II $\left(\mathrm{F}_{\mathrm{v}} / \mathrm{F}_{\mathrm{m}}\right)$ or performance index (PI) in leaves of the transplants and chlorophyll pigments content

\begin{tabular}{|c|c|c|c|c|c|}
\hline \multirow{2}{*}{ Crop } & \multirow{2}{*}{ Parameter } & \multicolumn{2}{|c|}{$\mathrm{F}_{\mathrm{v}} / \mathrm{F}_{\mathrm{m}}$} & \multicolumn{2}{|c|}{ PI } \\
\hline & & $\mathrm{r}$ & $\mathrm{p}$ & $r$ & $\mathrm{p}$ \\
\hline \multirow{3}{*}{ Cauliflower } & $\mathrm{Chl} a$ & 0.621 & $* *$ & 0.499 & $*$ \\
\hline & $\mathrm{Chl} b$ & 0.636 & $* *$ & 0.498 & $*$ \\
\hline & $\mathrm{Chl} a+b$ & 0.641 & $* *$ & 0.510 & * \\
\hline \multirow{3}{*}{ Broccoli } & Chl $a$ & 0.264 & ns & 0.414 & ns \\
\hline & $\mathrm{Chl} b$ & 0.385 & ns & 0.103 & ns \\
\hline & $\mathrm{Chl} a+b$ & 0.275 & ns & 0.415 & ns \\
\hline
\end{tabular}

Note $:^{*}, \mathrm{p}<0.05 ;{ }^{* *}, \mathrm{p}<0.01 ;^{* * *}, \mathrm{p}<0.001 ; \mathrm{ns}$, non-significant.

Table 4. Comparison of cauliflower and broccoli transplants response to chilling temperatures (means of the years 2011-2013)

\begin{tabular}{|c|c|c|c|c|c|c|c|}
\hline Crop & Temperature $\left({ }^{\circ} \mathrm{C}\right)$ & $\mathrm{Fv} / \mathrm{Fm}$ & PI & Car & Chl a & $\mathrm{Chlb}$ & Chl a: Chl b \\
\hline \multirow{3}{*}{ Cauliflower } & 6 & $0.544 \mathrm{a}$ & $1.765 \mathrm{a}$ & $30.33 \mathrm{a}$ & $113.50 \mathrm{a}$ & $55.88 \mathrm{a}$ & $2.031 \mathrm{c}$ \\
\hline & 10 & $0.684 b$ & $5.338 \mathrm{~b}$ & $30.58 \mathrm{a}$ & $118.11 \mathrm{a}$ & $59.11 \mathrm{ab}$ & $1.999 \mathrm{c}$ \\
\hline & 14 & $0.801 \mathrm{c}$ & $8.468 \mathrm{c}$ & $29.66 \mathrm{a}$ & $108.55 \mathrm{a}$ & $59.53 \mathrm{ab}$ & $1.824 \mathrm{a}$ \\
\hline \multirow{3}{*}{ Broccoli } & 6 & $0.781 \mathrm{c}$ & $6.378 \mathrm{~b}$ & $34.13 \mathrm{~b}$ & $121.40 \mathrm{a}$ & $63.26 \mathrm{~b}$ & $1.919 \mathrm{~b}$ \\
\hline & 10 & $0.768 c$ & $4.508 \mathrm{~b}$ & $31.89 \mathrm{ab}$ & $120.90 \mathrm{a}$ & $63.25 \mathrm{~b}$ & $1.912 \mathrm{~b}$ \\
\hline & 14 & $0.793 c$ & $4.628 \mathrm{~b}$ & $29.11 \mathrm{a}$ & $109.53 \mathrm{a}$ & $60.97 \mathrm{ab}$ & $1.797 \mathrm{a}$ \\
\hline Crop (C) & & $* * *$ & $\mathrm{~ns}$ & * & ns & $* *$ & $* * *$ \\
\hline Temperature $(\mathrm{T})$ & & $* * *$ & $* * *$ & $* *$ & $* *$ & ns & *** \\
\hline $\mathrm{C} \times \mathrm{T}$ & & $* * *$ & $* * *$ & $* * *$ & ns & $*$ & *** \\
\hline
\end{tabular}

Note: Data were subjected to two-way ANOVA. Means within a column followed by different letters are significantly different at $\mathrm{p}<0.05$ according to Tukey's HSD test; the level of significance $\left({ }^{*}, \mathrm{p}<0.05 ;{ }^{* *}, \mathrm{p}<0.01 ;^{* * *}, \mathrm{p}<0.001\right.$; ns, non-significant) for main effects (crop - C, temperature level - T), and interactions between them $(\mathrm{C} \times \mathrm{T})$ was also shown. Carotenoids and chlorophylls contents were expressed in $\mathrm{mg} 100 \mathrm{~g} \mathrm{FW}^{-1}$.

\section{Discussion}

In this study we answered what changes have occurred in the transplants of temperate-climate vegetable crops subjected to low temperature treatment. We determined the effects of chilling temperatures and its duration on photosynthetic activity of broccoli and cauliflower on the base of chlorophyll $a$ fluorescence indices and pigments content. We found the differences in response to chilling treatment of two tested Brassica crops: cauliflower and broccoli, pointing to the cauliflower plants as a more sensitive to low temperature.

In present study, chlorophyll a fluorescence indices of the cauliflower showed a significant effect of low temperature $\left(6^{\circ} \mathrm{C}\right)$. Such temperature applied to the cauliflower plants likely caused disruption to the photosynthetic apparatus after 1 week, and much stronger after 2 weeks of the treatment, which led to reduction in maximum quantum efficiency of PSII and performance index values. Decrease in the efficiency of PSII photochemistry may be connected with some damages of PSII or its down-regulation (Haldimann, 1997; Guidi and Degl'Innocenti, 2012), which is associated with the decrease activity of reaction centers and conformational changes in the light harvesting complexes of PSII (Ashraf and Harris, 2013). However, further research demonstrated that cauliflower plants treated with identical chilling variants were able to recover the photosynthetic apparatus efficiency during subsequent development in the field (Kalisz et al., 2014). Moreover, it was found that an application of $6^{\circ} \mathrm{C}$ resulted in significant increase of cauliflower yield. These findings showed that low temperature probably caused short-term decrease of the crop photosynthesis through down-regulation of PSII and not irreversible damages of the photosystem in a transplants stage. The plants had a potential to recover from chilling resulting later in higher crop productivity. In present study, $F_{v} / F_{m}$ and PI parameters of broccoli transplants was not affected by both chilling temperature and chilling duration, which was in contrast to cauliflower. It indicates lesser inhibition of the activity of PSII reaction centers and ability of the broccoli plants to protect effectively photosystem II.

In the experiment, the lowest temperature $\left(6^{\circ} \mathrm{C}\right)$ was applied together with an irradiance of $300 \mu \mathrm{mol} \mathrm{m} \mathrm{m}^{-2}$. Decreases in chlorophyll $a$ fluorescence indices $\left(\mathrm{F}_{\mathrm{v}} / \mathrm{F}_{\mathrm{m}}\right.$ and $\left.\mathrm{PI}\right)$ in cauliflower, but not in broccoli, indicated possible photoinhibition in the cauliflowers resulting from photooxidative damage (Powles et al., 2006). It suggested that at $6^{\circ} \mathrm{C}$, applied photosynthetically active radiation intensity was perceived as excess light and was potentially dangerous for photosystem components of cauliflower leaf tissues. However, when time of exposure and low temperature intensity are above lethal levels, the plants are able to recover their photosynthetic capacity (Bruce et al., 2007). Further studies on cauliflower plants, conducted in the field, confirmed this supposition (Kalisz et al., 2014). Second fluorescence parameter PI describes precise equilibrium between primary photosynthetic reactions and dark enzymatic reactions (Kalaji and Guo, 2008). According to the present results, the lowest applied chilling temperature $\left(6^{\circ} \mathrm{C}\right)$ disrupted this equilibrium in cauliflower transplants but not in broccoli leaves. Because fluorescence parameters are indicators of photosynthetic performance (Hasdai et al., 2006; Strauss et al., 2006), we determined, using $F_{v} / F_{m}$ and PI, intensity of response to chilling between both tested Brassica oleracea crops (cauliflower and broccoli), pointing to the photosynthetic apparatus of broccoli transplants as less vulnerable to low temperature than that of cauliflower.

There is lack of research concerning the changes of chlorophyll and carotenoid levels in response to low temperature for temperate-climate vegetable crops, such as cauliflower and broccoli, being in juvenile stage. In present study, there was no effect of chilling duration on broccoli chlorophyll $a$ and $b$ concentrations, but measured values for cauliflower were significantly lower after 2 weeks of chilling in comparison to plant chilled for 1 week. There was no reduction in chlorophylls by chilling temperature, the average content of chlorophyll $a$ was even higher in chilled broccoli 
22

leaves (for both low temperature levels) and in cauliflower $\left(10^{\circ} \mathrm{C}\right)$ than in the plants held in $14^{\circ} \mathrm{C}$. This is in contrast to results described in other reports for chill-sensitive plants (Aroca $e t$ al., 2001; Zang et al., 2010) and to results obtained by Hasdai et al. (2006) for Arabidopsis, belonging to Brassicaceae family. An explanation can be found in the work of Aghaee et al. (2011). They compared chlorophyll contents in juvenile rice of cold-sensitive and cold-tolerant genotypes stressed with low temperature (15/10 ${ }^{\circ} \mathrm{C}$ day/night) for 2 weeks. Although stressed plants had lower chlorophyll contents than control, much smaller decreases in coldtolerant rice genotypes suggest that light can be efficiently used in photosynthesis by these plants even under stressful conditions. More tolerant to low temperature crops like broccoli and cauliflower may not show a significant decrease of chlorophylls content in stress-induced conditions. Protective mechanisms in tested $B$. oleracea crops seemed to be more effective in relation to chill-sensitive plants, moreover, it worked more sufficiently in broccoli than in cauliflower transplants. Significant correlations between the chlorophyll contents and $\mathrm{F}_{\mathrm{v}} / \mathrm{F}_{\mathrm{m}}$ or PI in cauliflower transplants but not in broccoli were found. Lack of correlation between these parameters in the leaves of broccoli plants is likely due to different response of the crop to chilling.

Higher carotenoids concentration (statistically confirmed) in broccoli transplants treated with the low temperatures (6 and 10 ${ }^{\circ} \mathrm{C}$ ) was observed. This proves initiation of carotenoids biosynthesis in the plants during chilling. Carotenoids play important role in protecting photosynthesis apparatus against damage via their abilities to quench singlet molecular oxygen and to trap peroxyl radicals produced thus avoiding chlorophyll photooxidation (Haldimann, 1999). These compounds also stimulate energy dissipation within light-harvesting antenna proteins by non-photochemical quenching, or enhance lightharvesting capacity of chlorophylls to compensate reduced chlorophyll content under low temperature. In present study, we did not observed reduction in chlorophylls in chilled broccoli leaves, but an increase in total carotenoids content under lower temperatures occurred. It indicated that carotenoids were involved mainly in free radical scavenging mechanisms launched in the leaves of that transplants.

Results of present study showed a diversity response of tested B. oleracea crops to chilling. We did not find any research comparisons of the effect of low temperature on cauliflower and broccoli in one study, however, cauliflower plants are regarded as sensitive to environmental conditions (Wurr et al., 1990). As was reported by Dhugosz-Grochowska et al. (2012) for broccoli transplants, there was no visible outer symptoms of damage caused by very low temperature $\left(2{ }^{\circ} \mathrm{C}\right)$, the plants seem to be rather tolerant of low temperature, but still changes in the physiological and biochemical processes have occurred. A significant decrease of $\mathrm{F}_{\mathrm{v}} / \mathrm{F}_{\mathrm{m}}$ and PI in cauliflower transplants treated with chilling temperatures, observed in present study, and no changes in this regard noted for broccoli plants, suggests lower disturbances in photosynthetic activity of the latter in chilling conditions. No reduction in chlorophylls concentration was observed in both Brassica crops after chilling treatment, but increased accumulation of carotenoids in broccoli leaves showed that they perform an essential photoprotective role by quenching triplet state chlorophyll molecules and scavenging reactive oxygen species formed within the chloroplast. Probably increased carotenoids content was connected with lack of negative effects of low temperature action on chlorophyll $a$ fluorescence parameters in the case of broccoli plants.

\section{Conclusion}

We showed that the response of the photosynthetic apparatus, described by chlorophyll a fluorescence, to low temperature is more distinct in the case of cauliflower transplants than in broccoli. A temperature of $6^{\circ} \mathrm{C}$ applied during 1 or 2 weeks decreased the PI and $F_{v} / F_{m}$ of the cauliflower leaves. Chilling duration, as a long-acting stimulus, seemed to be determinant for chlorophyll concentrations, especially in cauliflower plants, than temperature level itself. We observed accelerated biosynthesis of carotenoids in broccoli transplants acting as protective compounds against ROS under low temperature. In the case of cauliflower, chlorophyll $a$ fluorescence was a useful tool for screening the physiological response of the plants to low temperature, while biochemical analyses did not show any significant changes in the levels of photosynthetic pigments, such as chlorophylls or carotenoids. According to the results of this study, we must indicate that broccoli and cauliflower plants, as natural varieties of $B$. oleracea species with similar biology, showed different responses to chilling applied in the same manner, pointing to broccoli as less sensitive to low temperature at juvenile stage.

\section{Acknowledgments}

This work was supported by the National Science Centre, Poland, grant number N N310 305239 and statutory activity funds DS 3500 .

\section{References}

Aghaee A, Moradi F, Zare-Maivan H, Zarinkamar F, Irandoost HP, Sharifi $\mathrm{P}$ (2011). Physiological responses of two rice (Oryza sativa $\mathrm{L}$ ) genotypes to chilling stress at seedling stage. African Journal of Biotechnology 10:7617-7621.

Aroca R, Irigoyen JJ, Sánchez-Díaz M (2001). Photosynthetic characteristics and protective mechanisms against oxidative stress during chilling and subsequent recovery in two maize varieties differing in chilling sensitivity. Plant Science 161:719-726.

Ashraf M, Harris PJC (2013). Photosynthesis under stressful environments: Anoverview.Photosynthetica 51(2):163-190.

Bhattacharjee S (2005). Reactive oxygen species and oxidative burst: Roles in stress, senescence and signal transduction in plant. Current Science 89:1113-1121.

Bruce TJA, Matthes MC, Napier JA, Pickett JA (2007). Stressful "memories" of plants: evidence and possible mechanisms. Plant Science 173(6):603-608.

Diputado MT (1989). Growth and development studies with broccoli (Brassica oleracea var. italica).PhD Thesis, Massey Univ, NewZealand.

Dhugosz-Grochowska O, Leja M, Grabowska A, Kunicki E (2012). The effect of preliminary chilling of broccoli transplants on some antioxidative parameters. Folia Horticulturae 24(2):131-139.

Dutta S, Mohanty S, Tripathy BC (2009). Role of temperature stress on chloroplast biogenesis and protein import in pea. Plant Physiology 150(2):1050-1061.

Gorbe E, Calatayud A (2012). Applications of chlorophyll fluorescence imaging technique in horticultural research: A review. Scientia Horticulturae 138:2435. 
Grabowska A, Kunicki E, Kalisz A, Wojciechowska R, Leja M, Sękara A (2014). Chilling stress applied to broccoli transplants of different age affects yield of the plants cultivated in summer. Horticultural Science (Prague) 41(2):71-79.

Guidi L, Deg'Innocenti E (2012). Chlorophyll a fluorescence in abiotic stresses. In: Venkateswarlu B, Shanker AK, Shanker Ch, Maheswari M (Eds). Crop Stress and its Management: Perspectives and Strategies. Springer Netherlands, Dordrecht, The Netherlands pp 359-399.

Gururani MA, Venkatesh J, Tran L-SP (2015). Regulation of photosynthesis during abiotic stress-induced photoinhibition. Molecular Plant 8:13041320.

Habibi F, Normahamadi H, Sharifabad A, Eivazi A, Heravan M (2011). Effect of cold stress on cell membrane stability, chlorophyll $a$ and $b$ contain and proline accumulation in wheat (Triticum aestivum L.) variety. African Journal of Agricultural Research 6:58545859.

Haldimann P (1997). Chilling-induced changes to carotenoid composition, photosynthesis and the maximum quantum yield of photosystem II photochemistry in two maize genotypes differing in tolerance to low temperature. Journal of Plant Physiology 151:610-619.

Haldimann $P$ (1999). How do changes in temperature during growth affect leaf pigment composition and photosynthesis in Zea mays genotypes differing in sensitivity to low temperature? Journal of Experimental Botany 50(333):543-550.

Hasanuzzaman M, Nahar K, Fujita M (2013). Extreme temperature responses, oxidative stress and antioxidant defense in plants. In: Vahdati $\mathrm{K}$,Leslie Ch (Eds). Abiotic Stress - Plant Responses and Applications in Agriculture.InTech, Rijeka, Croatia pp 169-205.

Hasdai M, Weiss B, Levi A, Samach A, Porat R (2006). Differential responses of Arabidopsis ecotypes to cold, chilling and freezing temperatures. Annals of Applied Biology 148:113-120.

Jansen M, Gilmer F, Biskup B, Nagel KA, Rascher U, Fischbach A, Briem S, Dreissen G, Tittmann S, Braun S, De Jaeger I, Metzlaff M, Schurr U, Scharr H, Walter A (2009). Simultaneous phenotyping of leaf growth and chlorophyll fluorescence via GROWSCREEN FLUORO allows detection of stress tolerance in Arabidopsis thaliana and other rosette plants. Functional Plant Biology 36:902-914.

Kalaji HM, Guo P (2008). Chlorophyll fluorescence: a useful tool in barley plant breeding programs. In: Sanches A, Gutierrez SJ (Eds). Photochemistry Research Progress. Nova Science Publishers Inc, Hauppauge, NY, USA pp 447-471.

Kalisz A, Sękara A, Cebula S, Grabowska A, Kunicki E (2014). Impact of low-temperature transplant treatment on yield and quality of cauliflower curds in late spring production. Scientia Horticulturae 176:134142.

Kato Y, Sakamoto W (2014). Phosphorylation of photosystem II core proteins prevents undesirable cleavage of $\mathrm{D} 1$ and contributes to the finetuned repair of photosystem II. The Plant Journal 79:312-321.

Kingston-Smith AH, Harbinson J, Foyer CH (1999). Acclimation of photosynthesis, $\mathrm{H}_{2} \mathrm{O}_{2}$ content and antioxidants in maize (Zea mays) grown at sub-optimal temperatures. Plant, Cell \& Environment 22:1071-1083.

Kratsch HA, Wise RR (2001). The ultrastructure of chilling stress. Plant, Cell \&Environment 23:337-350.
Lichtenthaler HK, Wellburn AR (1983). Determinations of total carotenoids and chlorophylls a and b of leaf extracts in different solvents. Biochemical Society Transactions 603:591-592.

Liu P, Meng Q-W, Zou Q, Zhao S-J, Liu Q-Z (2001). Effects of coldhardening on chilling-induced photoinhibition of photosynthesis and on xanthophylls cycle pigments in sweet pepper. Photosynthetica 39(3):467-472.

Lukatkin AS, Brazaityté A, Bobinas Č, Duchovskis P (2012). Chilling injury in chilling-sensitive plants: A review.Žemdirbyste 99(2):111-124.

Mishra A, Mishra KB, Höermiller II, Heyer AG, Nedbal L (2011). Chlorophyll fluorescence emission as a reporter on cold tolerance in Arabidopsis thaliana accessions. Plant Signaling \& Behavior 6(2):301310.

Murata N, Takahashi S, Nishiyama Y, Allakhverdievd SI (2007). Photoinhibition of photosystem II under environmental stress. BBABioenergetics 1767(6):414-421.

Nishiyama Y, Allakhverdiev SI, Murata N (2011). Protein synthesis is the primary target of reactive oxygen species in the photoinhibition of photosystem II. Physiologia Plantarum 142:35-46.

Olesen JE, Grevsen K (2000). A simulation model of climate effects on plant productivity and variability in cauliflower (Brassica oleracea L. botrytis). Scientia Horticulturae 83:83-107.

Oliveira JG, Da Costa Aguiar Alves PL, Vitoria AP (2009). Alterations in chlorophyll a fluorescence, pigment concentrations and lipid peroxidation to chilling temperature in coffee seedlings. Environmental and Experimental Botany 67:71-76.

Partelli FL, Vieira HD, Viana AP, Batista-Santos P, Rodrigues AP, Leitão AE, Ramalho JC (2009). Low temperature impact on photosynthetic parameters of coffee genotypes. Pesquisa Agropecuária Brasileira 44(11):1404-1415.

Perveen S, Shinwari KI, Jan M, Malook I, Rehman S, Khan MA, Jamil M (2013). Low temperature stress induced changes in biochemical parameters, protein banding pattern and expression of Zat12 and Myb genes in rice seedling. Journal of Stress Physiology \& Biochemistry 9(4):193-206.

Pospisisil P, (2012). Molecular mechanisms of production and scavenging of reactive oxygen species by photosystem II. Biochimica et Biophysica Acta 1817:218-231.

Powles SB, Berry JA, Björkman O (2006). Interaction between light and chilling temperature on the inhibition of photosynthesis in chilling-sensitive plants. Plant, Cell \&Environment 6(2):117-123.

Ruelland E, Zachowski A (2010). How plants sense temperature. Environmental and Experimental Botany 69:225-232.

Ruelland E, Vaultier M-N, Zachowski A, Hurry V (2009). Cold signaling and cold acclimation in plants. Advances in Botanical Research 49:35150.

Sharma P, Jha AB, Dubey RS, Pessarakli M (2012). Reactive oxygen species, oxidative damage, and antioxidative defense mechanism in plants under stressful conditions. Journal of Botany, ID 217037.

Strasser RJ, Tsimilli-Michael M, Srivastava A (2004). Analysis of the fluorescence transient. In: Papageorgiou C, Govindjee (Eds). Chlorophyll Fuorescence: a Signature of Photosynthesis. Advances in 
24

Photosynthesis and Respiration Series. Springer Netherlands, Dordrecht, The Netherlands pp.321-362.

Strauss AJ, Krüger GHJ, Strasser RJ, Van Heerden PDR (2006). Ranking of dark chilling tolerance in soybean genotypes probed by the chlorophyll a fluorescence transient O-J-I-P. Environmental and Experimental Botany 56:147-157.

Sun Y-P,ZhangZ-P, Xu C-X, Shen C-M, Gao C, ChongL-J (2009).Effect of ALA on fast chlorophyll fluorescence induction dynamics of watermelon leaves under chilling stress. Acta Horticulturae Sinica 36(5):671-678.

Suzuki N, Mittler R (2006). Reactive oxygen species and temperature stresses: A delicate balance between signaling and destruction. Physiologia Plantarum 126:45-51.

Suzuki N, Koussevitzky S, Mittler R, Miller G (2011). ROS and redox singaling in the response of plants to abiotic stress. Plant, Cell \& Environment 35:259-270.

Thakur P, Nayyar H (2013). Facing the cold stress by plants in the changing environment: sensing, signaling, and defending mechanisms. In: Tuteja N, Gill SS (Eds). Plant Acclimation to Environmental Stress. Springer Science+Business Media, NY,USA pp. 29-69.

Theocharis A, Clément Ch, Barka EA (2012). Physiological and molecular changes in plants grown at low temperatures. Planta 235:1091-1105.
Turan O, Ekmekci Y (2011). Activities of photosystem II and antioxidant enzymes in chickpea (Cicer arietinum L.) cultivars exposed to chilling temperatures. Acta Physiologiae Plantarum 33:67-78.

Van Heerden PDR, Viljoen MM, De Villiers MF, Krüger GHJ (2004). Limitation of photosynthetic carbon metabolism by dark chilling in temperate and tropical soybean genotypes. Plant Physiology and Biochemistry 42:117-124.

Wang Y-J,Zhang Z-G, He X-J, Zhou H-L, Wen Y-X, Dai J-X, ZhangJ-S, Chen S-Y (2003). A rice transcription factor OsbHLH1 is involved in cold stress response. Theoretical and Applied Genetics 107:1402-1409.

Wurr DCE, Fellows JR, Hiron RWP (1990). The effect of field environmental conditions on the growth and development of four cauliflower cultivars. Journal of Horticultural Science 65(5):565-572.

Yadegari LZ, Heidari R, Carapetian J (2007). The influence of cold acclimation on proline, malondialdehyde (MDA), total protein and pigments contents in soybean (Glycine max) seedling. Journal of Biological Sciences 7:1141-1436.

Zhang YH, Chen LJ, He JL, Qian LS, Wu LQ, Wang RF (2010). Characteristics of chlorophyll fluorescence and antioxidative system in super-hybrid rice and its parental cultivars under chilling stress. Biologia Plantarum54(1):164168. 